\title{
ZPRACOVÁNÍ DAT LASEROVÉHO SKENOVÁNÍ PÍSKOVCOVÝCH SKAL Z UAV
}

\author{
Michaela TOMKOVÁ ${ }^{1}$, Jakub LYSÁK ${ }^{1}$ \\ ${ }^{1}$ Katedra aplikované geoinformatiky a kartografie, Přírodovědecká fakulta, Univerzita Karlova, \\ Albertov 6, 128 43, Praha 2, Česká republika \\ \{michaela.tomkova\},\{jakub.lysak\}@natur.cuni.cz \\ doi: https://doi.org/10.31490/9788024843988-8
}

\begin{abstract}
Abstrakt
Příspěvek popisuje praktické zkušenosti autorů s terénním sběrem dat pomocí lidaru miniVUX-1UAV od společnosti RIEGL upevněném na dronu DJI Matrice 600 Pro a jejich následným zpracováním v rozdílných nástrojích. Vzhledem ke specifickým vlastnostem pískovcového terénu a požadavkům na vysokou hustotu výsledného bodového mračna nebyly terénní práce rutinní ani z pohledu profesionálních pilotů z firmy UpVision, kteři dron řídili. Cílem celého projektu je zhodnocení vlivu hustoty dat na tvary skal ve výsledném digitálním modelu reliéfu a navržení postupu filtrace, která by spolehlivě fungovala $i \mathrm{v}$ takto extrémně členitém terénu. Zpracování pořízených dat tedy směřuje ke klasifikovanému bodovému mračnu, které poslouží jako referenční dataset $v$ dalších krocích projektu.
\end{abstract}

\begin{abstract}
The paper is focused on practical experience of authors with field data collection using lidar miniVUX-1UAV from RIEGL mounted on DJI Matrice 600 Pro and their subsequent processing using different tools. Due to the specific conditions of the sandstone terrain and the high density requirements of the resulting point cloud, the field work was not routine even from the perspective of professional pilots from UpVision who controlled the drone. The aim of the whole project is to evaluate the effect of data density on the rock shapes in the resulting digital relief model and to propose a filtration procedure that would work reliably even in such an extremely rugged terrain. The processing of the collected data is thus directed to a classified point cloud, which will serve as a reference dataset in the next project steps.
\end{abstract}

Klíčová slova: laserové skenování; pískovcová skalní města; UAV; bodové mračno; manuální filtrace Keywords: laser scanning; sandstone landscape; UAV; point cloud; manual filtration 


\section{ROZŠíŘENÝ ABSTRAKT}

Podrobné mapování těžko prístupného zalesněného terénu, který nalezneme $v$ oblastech pískovcových skalních měst, je dnes možné především díky metodě leteckého laserového skenování (LLS), která do určité míry umožňuje "nahlédnout pod vegetaci" a získat údaje o terénu pod ní. Celoplošné skenování území České republiky proběhlo již v letech 2009 - 2013 a jedním z výsledných produktů je DMR 5G s hustotou bodů okolo 1,5 bodu $/ \mathrm{m}^{2}$. Praktické zkušenosti ukazují, že tato hustota není dostatečná pro spolehlivé rozlišení skalních útvarů od vegetace a ve výsledném modelu pak vznikají chyby - nejčastěji je $v$ něm existující skalní útvar vynechán (Lysák, 2016; Tomková, 2018). Výzkum, v rámci kterého vznikl i tento príspěvek, si tedy mimo jiné klade za cíl najít odpověd’ na to, $s$ jakou hustotou by bylo vhodné skalní města skenovat, aby bylo možné data úspěšně automaticky filtrovat a vytvořit tak digitální model terénu využitelný $\mathrm{k}$ dalším aplikacím, například ke zpřesnění reprezentace skalních útvarů $\mathrm{v}$ digitálních topografických databázích.

\section{Pořízení dat}

Data pro účely výzkumu byla pořízena pomocí laserového skeneru miniVUX-1UAV od společnosti RIEGL připevněném na dronu DJI Matrice 600 Pro (obr. 1). Mezi hlavní přednosti tohoto skeneru patří malé rozměry a hmotnost, které umožňují použití dronu jako nosiče, a skenování s frekvencí $100 \mathrm{kHz}$ s rozmítáním svazků laserových paprsků pomocí rotačního zrcadla do všech směrů $\left(360^{\circ}\right.$ field-of-view). $Z$ navráceného signálu je prístroj schopen rozpoznat až 5 rozdílných odrazů (RIEGL, 2020). Pro skenování byly vybrány čtyři různé, geomorfologicky odlišné pískovcové krajiny: Vidimské lávky na Kokořínsku, okolí Pravčické brány v Národním parku České Švýcarsko, centrální část Adršpašského skalního města a Skalní ostrov $v$ Teplických skalách (tab. 1). Na poslední zmíněné lokalitě bylo nutné létání o rok odložit.

Tab. 1. Přehled skenovaných lokalit a parametrů výsledných dat

\begin{tabular}{llrrrr}
\hline lokalita & $\begin{array}{l}\text { datum } \\
\text { skenování }\end{array}$ & $\begin{array}{r}\text { počet bodů } \\
\text { celkem }\end{array}$ & $\begin{array}{r}\text { počet bodů } \\
\text { posledního } \\
\text { odrazu }\end{array}$ & $\begin{array}{r}\text { hustota } \\
\text { bodového } \\
\text { mračna } \\
\text { [bodů/m²] }\end{array}$ & $\begin{array}{r}\text { hustota bodů } \\
\text { posledního } \\
\text { odrazu } \\
\text { [bodů/m²] }\end{array}$ \\
\hline Vidimské lávky & 15.10 .2019 & 67443373 & 39490494 & 635,97 & 371,68 \\
Pravčická brána & 19.11 .2019 & 132977784 & 89572178 & 1334,10 & 892,07 \\
Adršpašské skalní město & 18.12 .2019 & 196495745 & 143296081 & 833,77 & 605,68
\end{tabular}

Teplické skalní město pröripravováno na podzim 2020

Sběr dat $s$ využitím dronu $v$ tomto typu terénu přináší řadu výzev. Kromě těch faktorů, které ovlivňují létání $s$ dronem obecně (tedy především teplota a vítr), zde vstupuji do hry i další. Specifikem je výběr ročního období: z hlediska použití technologie LLS je ideální předjaří, kdy nejsou na stromech ještě listy a zemský povrch je po zimě slehlý. To ovšem nepřipadá $v$ úvahu $z$ hlediska ochrany prírody, protože $v$ řadě lokalit ( $z$ našeho výběru ve 3 ze 4 uvedených) hnízdí chránění dravci, které by pohyb UAV rušil. Skenování tedy bylo provedeno pozdě na podzim, na Kokořínsku ještě před úplným opadáním listí, ve zbylých dvou lokalitách později po opadu. Pozdější termíny ovšem přináší problémy z hlediska počasí (podzimní mlhy, nízké teploty snižující výdrž baterií, riziko, že napadne sníh, přes který se paprsek laseru $k$ terénu nedostane). Nevýhodou tohoto období je také relativně krátký den. Technologii LLS sice zhoršené světelné podmínky neovlivňují, což bylo neúmysIně prakticky ověřeno ve dvou lokalitách, kde se skenování dokončovalo za šera, ale pro létání s dronem a následný návrat náročným terénem je tma nevhodná. 

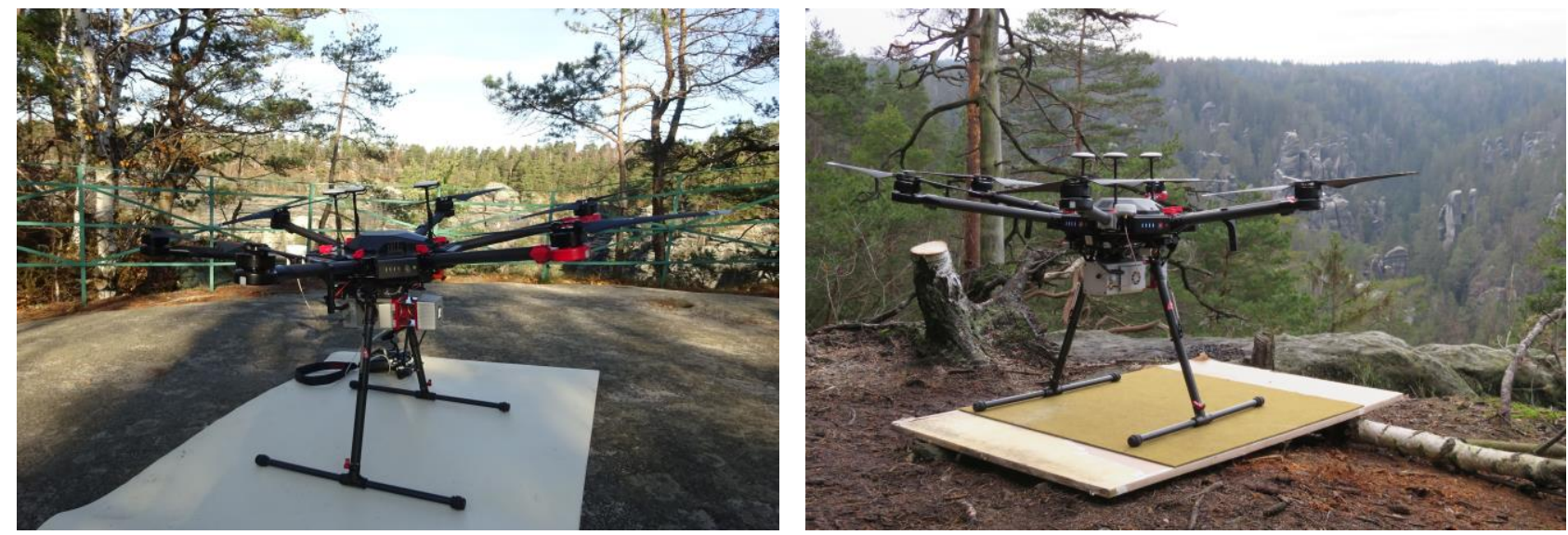

Obr. 1. Dron s laserovým skenerem na improvizované startovací ploše

(vlevo v Českém Švýcarsku - foto Jakub Lysák, vpravo v Adršpašských skalách - foto Petr Kuna)

V zalesněném členitém terénu skalních měst je často obtižné najít místa, odkud skenování provádět. Ideální jsou oblasti na plošinách či vrcholcích skal, z nichž je výhled na pohyb dronu při skenování. S ohledem na hmotnost zařízení je žádoucí, aby tato místa byla co nejbliže sjízdným nebo alespoň schůdným komunikacím, které ale většinou vedou po dně údolí a roklí. Odtud ale skenování nepríipadá príliš v úvahu, protože údolí jsou často zarostlá stromy a z úzkých roklí je výhled na oblohu omezený. Samotné plánování letu vyžaduje vzhledem k extrémní výškové členitosti terénu pečlivou přípravu, kdy je snaha terén sledovat $v$ rámci možností $v$ konstantní výšce nad ním, aby bylo dosaženo rovnoměrné hustoty výsledného bodového mračna. Ve většině případů probíhalo skenování sice podle předpřipraveného letového plánu, ale v manuálním režimu s kontrolou výšky, rychlosti a dostatečného odstupu od vegetace. To klade náročné požadavky na pilota.
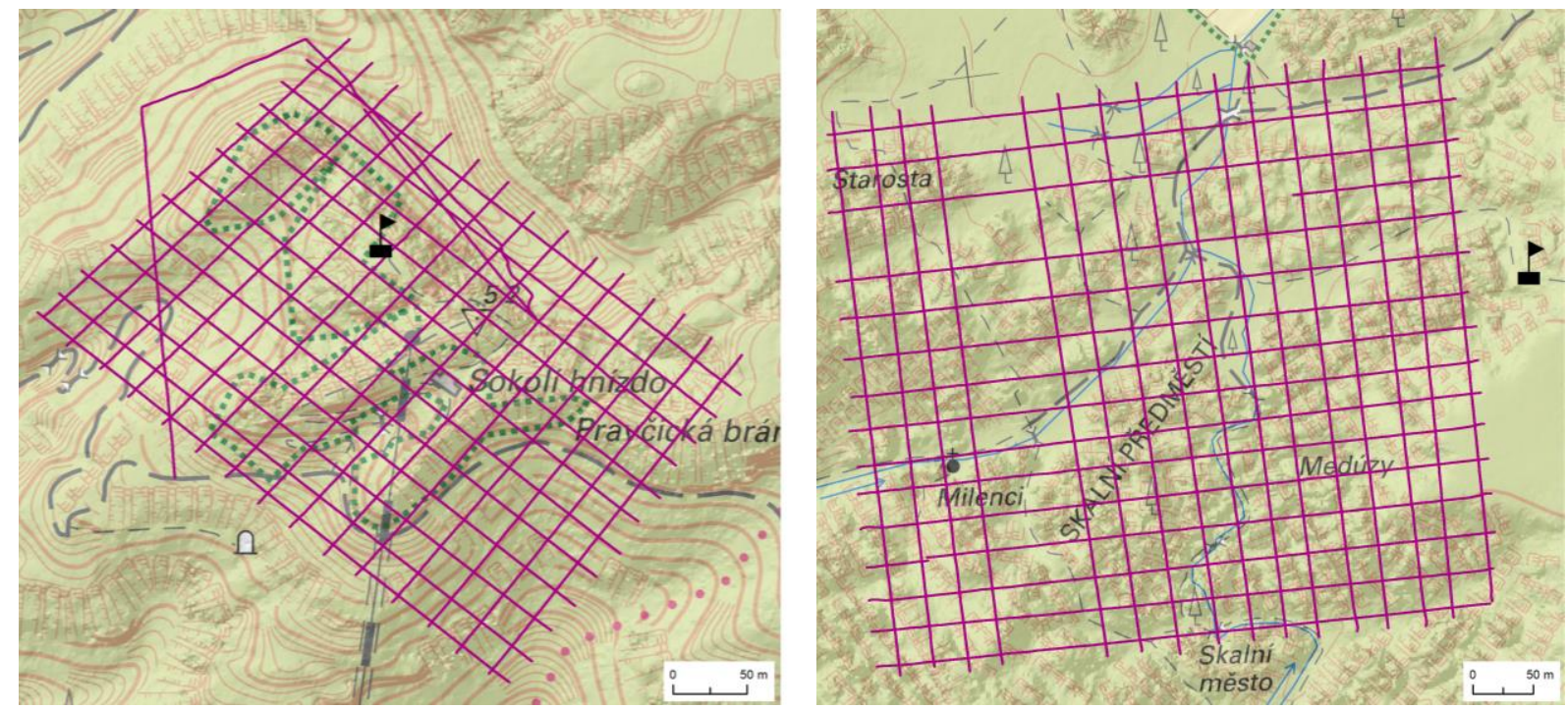

Obr. 2. Trajektorie letů nad Pravčickou bránou (vlevo) a v Adršpašských skalách (vpravo)

Trajektorie jsou znázorněné fialovou barvou a bod s vlaječkou představuje místo, odkud dron startoval. Podkladová mapa a stínovaný reliéf: @ ČúZK, 2020.

V lokalitě Pravčická brána byl křižový nálet ještě doplněn letem kolem části skalních stěn z nižší výšky kvůli zachycení většího množství detailů. $Z$ důvodu technických problémů nebyly v Adršpašských skalách naskenovány téměř celé dvě letové linie. Vzhledem k velkému překrytu sousedních letových řad a křižovému náletu tato chyba nemá zásadní vliv na výslednou hustotu bodového mračna. 
Sestavení letového plánu znamenalo hledání kompromisu mezi velikostí naskenované oblasti a kvalitou a hustotou výsledného bodového mračna. Přestože skener umožňuje skenovat s neomezeným field-of-view, u odrazů od vzdálených objektů prì "pohledu do strany" klesá polohová přesnost výsledných bodů. Zároveň tím vznikají zákryty a stíny a to $v$ tomto členitém terénu znamená chybějící informace o průběhu terénu $v$ roklích a puklinách a u paty skalních stěn a věží. Aby se zákryty eliminovaly, byl rozestup letových linií nastaven jen na zhruba 25 metrů a navíc byly lokality v Českém Švýcarsku a Adršpašských skalách nalétány křižem (obr. 2). Velikost naskenované oblasti pak byla omezena také množstvím dostupných baterií, které nebylo možné na místě nabíjet, a také omezenou dobou, kdy je světlo.

\section{Zpracování dat}

Prvotní zpracování naskenovaných dat proběhlo v softwarech PosPac od společnosti Applanix a RiProcess od výrobce skeneru firmy RIEGL. První zmíněný software umožňuje vytvoření trajektorií na základě dat naměřených pomocí GNSS prijijímače a IMU během skenování. $V$ našem príipadě byl navíc průběh trajektorií zpřesněn pomocí virtuální referenční stanice s využitím dat CZEPOS. Pomocí trajektorií je možné ze surových naskenovaných dat vytvorit bodové mračno v software RiProcess. Bez dalších úprav obsahuje takové mračno veškeré zaznamenané odrazy $v$ celém možném rozsahu, což je sice výhodné $z$ pohledu vyšší hustoty dat, ale za cenu snižené přesnosti relativního vyrovnání pásů. $Z$ tohoto důvodu jsme pristoupili $\mathrm{k}$ ořezu dat na $90^{\circ}$ field-of-view, čímž bylo sice ztraceno okolo $25 \%$ bodů, ale chyba prí vyrovnání pásů byla snížena o několik centimetrů na výslednou hodnotu střední polohové chyby $2-5 \mathrm{~cm}$ v závislosti na lokalitě. Zůstává ovšem otázka, na kolik je takové vyrovnání pásů vůbec spolehlivé, když pro své výpočty hledá vzájemně si odpovídající roviny v bodovém mračnu, kde se roviny prakticky nevyskytují. Vizuální kontrola výsledných dat nám ukazuje, že je situace napříč bodovým mračnem proměnlivá a je možné nalézt jak místa, kde jsou data velmi dobře slícovaná, tak i taková, kde jsou jednotlivé pásy od sebe viditelně posunuté (obr. 3 vlevo).

Absolutní přesnost bodového mračna bude ověřena po zaměření snadno identifikovatelných bodů $v$ zájmové oblasti pomocí geodetického GNSS přijímače. V prípadě Pravčické brány Ize tento úkol alespoň lokálně provést bez větším obtíží, protože je možné se pohybovat po plošině na vrcholu skal, kde je i množství relativně ostrých hran, jejichž polohu lze odečíst $\mathrm{i} z$ bodového mračna, například na hraně schodů. Problematičtěji se jeví lokalita $\vee$ Adršpašských skalách, kde se Ize na vrcholky věží dostat jen s horolezeckým vybavením a na dně roklí je príijímaný GNSS signál omezený okolní vegetací a skalními útvary. $Z$ pohledu dalšího zpracování dat $v$ rámci projektu není absolutní polohová přesnost dat úplně stěžejní, protože záleží spiše na vzájemné poloze objektů a bodů v bodovém mračnu.

Vyexportované bodové mračno ze softwaru RiProcess ve formátu las je dále zpracováváno $v$ prostředí ArcGIS 10.6 a nástroji LASTools verze 191111 (Isenburg, 2019). Cílem prvního kroku projektu, který vzhledem ke své časové náročnosti dosud nebyl dokončen, je klasifikované bodové mračno $s$ rozlišením terénních a neterénních bodů. Výsledky klasifikace dostupné v ArcGIS jako funkce Classify LAS Ground (i po opakovaném použití s možností využití výsledků předchozí klasifikace - Esri, 2017) se ukázaly jako nedostatečné a vzhledem $\mathrm{k}$ absenci informací o použitém algoritmu a možnosti nastavení parametrů nebyl tento přístup zpracování využit. Místo toho byla využita funkce lasground_new z nástrojů LASTools, která je založena na algoritmu postupného zhuštování TIN s množstvím parametrů, díky kterým je možné přizpůsobit funkci bodovým mračnům $\mathrm{s}$ rozdílnými vlastnostmi. Ani popsaná filtrace $\mathrm{s}$ využitím velmi podrobného hledání iniciálních bodů, malým krokem a poměrně volně zvolenou hodnotou možné vzdálenosti nově príianého bodu od již vytvořeného povrchu si ovšem nedokázala poradit se strmými, př́padně i převislými stěnami, které označila jako neterénní objekty (obr. 3 vpravo). $Z$ tohoto důvodu je bodové mračno dále zpracováváno manuální interaktivní prací. Jedním z nástrojů, které tuto funkcionalitu nabízejí, je ArcMap s využitím výběru a změny třídy vybraných bodů v LAS Dataset Profile View prostředí (ArcGIS Pro zatím tuto funkci nemá). Jak název napovídá, úpravy probíhají jen ve $2 \mathrm{D}$ profilu, nikoliv ve 3D view nebo klasickém 2D půdorysném náhledu. To je hlavní příčinou velké časové náročnosti zpracování. 


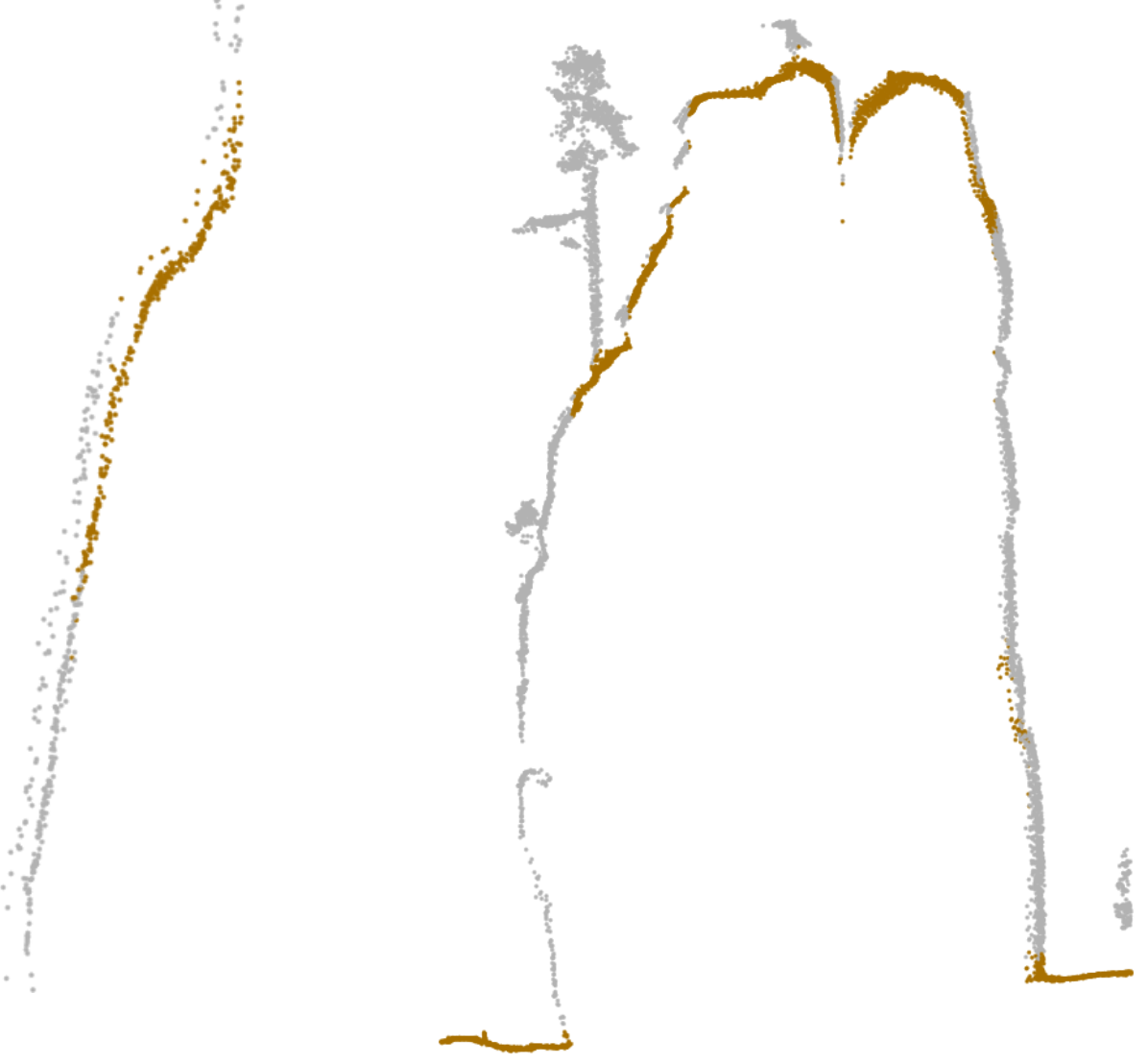

Obr. 3. Profily bodovým mračnem

Vlevo je viditelné vzájemné posunutí letových pásů zhruba o $20 \mathrm{~cm}$ na stěně skalní věže Milenci v Adršpašských skalách. Profil vpravo představuje ukázku nedokonalé automatické filtrace, která na stěnách skalní věže Uhliřská zanechala velké množství bodů označených jako neterénní - šedé. Terénní body mají hnědou barvou.

\section{Závěr}

Provedené skenování i přes určité logistické a technické potíže ukázalo použitelnost této technologie pro podrobné a přesné mapování zalesněných pískovcových krajin. Podle znalosti autorů jde vůbec o první experimenty $\mathrm{s}$ laserovými daty pořízenými dronem $v$ tomto typu terénu $v$ Česku. Relativně vysoká hustota pořízených dat přináší na jednu stranu výhody v podobě možnosti dobré identifikace jednotlivých objektů při manuální vizuální interpretaci, na druhou stranu také nové problémy při tvorbě digitálních modelů reliéfu, například se zpracováním převisů, kde standardní algoritmy filtrace nefungují.

Naskenování všech pískovcových oblastí v republice $s$ uvedenou hustotou bodového mračna se $v$ tuto chvíli nejeví jako realizovatelný a smysluplný úkol. Jako důležité budoucí využití pořízených dat vnímají autoři jejich využití pro zodpovězení otázky, jaká hustota bodového mračna je pro účely spolehlivého topografického mapování pískovcových skal potřebná a účelná. Jinými slovy, s jakou hustotou dat Ize ještě odlišit vegetaci od jednotlivých skalních útvarů a do jaké míry Ize tento postup automatizovat. Budoucí experimenty tedy předpokládají využití zředění pořízeného bodového mračna, jeho automatizovanou klasifikaci a vyhodnocení úspěšnosti tohoto procesu $s$ využitím referenčního manuálně zkontrolovaného bodového mračna. Výsledky těchto experimentů pak mohou mít praktický dopad pro budoucí topografické mapování pískovcových skalních měst $s$ využitím technologie leteckého laserového skenování $v$ širším měřítku, protože praktické zkušenosti ukazují, že spolehlivost stávajícího DMR $5 \mathrm{G}$ z hlediska zachycení skalních útvarů může být $v$ těchto oblastech poměrně problematická. 


\section{PODĚKOVÁNÍ}

Tento příspěvek vznikl s podporou GA UK v rámci projektu Detekce a rozpoznávání objektů v bodovém mračnu laserového skenování z pískovcových skalních měst (č. 132119).

\section{LITERATURA}

Esri (2017) ArcGIS Help - Classify LAS Ground. URL: https://desktop.arcgis.com/en/arcmap/10.5/tools/3danalyst-toolbox/classify-las-ground.htm, cit. 4. 3. 2020

Isenburg, M. (2019) LAStools - efficient tools for LiDAR processing. URL: https://rapidlasso.com/lastools/, cit. 4. 3. 2020

Lysák, J. (2016) Topografické mapování skalních útvarů s využitím dat leteckého laserového skenování. Dizertační práce na Př́rodovědecké fakultě Univerzity Karlovy, Praha

RIEGL (2020) RIEGL miniVUX-1UAV. URL: http://www.riegl.com/products/unmanned-scanning/rieglminivux-1uav, cit. 4. 3. 2020

Tomková, M. (2018) Klasifikace dat leteckého laserového skenování v pískovcových skalních městech. Diplomová práce na Př́rodovědecké fakultě Univerzity Karlovy, Praha 